\title{
Direct vitreous reaction to intraocular lens implants *
}

\author{
J. Reimer Wolter \\ The Departments of Ophthalmology and Pathology of the University of Michigan Hospitals, Ann Arbor, Michigan, USA
}

\begin{abstract}
Three intraocular lens implants removed during keratoplasty between $1 \frac{1}{2}$ and 5 years after implantation revealed attachments of reactive vitreous strands and membranes. These strands and membranes contained bundles of fibers with associated small bipolar cells, pigment, and blood remnants. Some of the fibrous vitreous strands were wound around the haptics of the implants for firm anchoring. The usual reactive cell membranes on the surface of the implants were interrupted in the areas of the attachment of formed vitreous and vitreous membranes.
\end{abstract}

Zusammenfassung. Drei intraokuläre Linsen, die zwischen $1 \frac{1}{2}$ und 5 Jahre nach der Implantation während Hornhautverpflanzungen entfernt wurden, zeigten fest anheftende reaktive Glaskörperstränge und verdickte Membranen. Diese enthielten Faserbündel mit zugehörigen kleinen bipolaren Zellen, Pigment und Blutresten. Einige dieser fibrösen Glaskörperstränge waren um die Haptik der Linsenprothesen herumgewunden und damit fest verankert. Die regulären Zellmembranen auf der Oberfläche der Linsenprothesen waren im Bereich der Verbindung mit geformtem Glaskörper und Glaskörpermembranen unterbrochen.

Mature vitreous under normal conditions does not appear to be a living structure in the sense of metabolically active cells or cellular formations. However, vitreous certainly can react under all kinds of pathological involvements and conditions. It can not only undergo local or general separation from the retina, liquifaction, so-called fibrosis, and shrinkage, but it can also exhibit more complex changes which may be very important clinically [1-6]. Clinicians talk about vitreous retraction, as if this is an active process somewhat like the reaction of small muscle fibers or cellular scar tissue. It has been said that this starts out with the formation of liquid pools and strands of collagen fibers [6], but in spite of a quickly enlarging nomenclature to describe the involved clinical, histochemical, and morphological details, the basic nature of most types of vitreous reaction still remains obscure. Experienced clinicians treat the vitreous

\footnotetext{
* Supported by The Research To Prevent Blindness, Inc., New York

Offprint requests to: J. Reimer Wolter, M.D., Department of Ophthalmology, University of Michigan Hospitals, Ann Arbor, Michigan 48109 , USA
}

very carefully. Their fear of unpredictable and dangerous vitreous reactions following surgery is best examplified by the statement of one of my early teachers, who liked to paraphrase Goethe by saying: "vitreous is a very special juice". A new generation of eye surgeons does not show much fear for vitreous reactions; they simply cut it up and aspirate it. However, only time will allow for a final and totally objective view about such aggressive management of the vitreous.

Vitreous is very evasive and its pathology usually is neglected. Meaningful histopathological information is difficult to get, since the dehydration necessary for this type of study causes artifacts as well as loss of the three-dimentional arrangement of its delicate components. However, vitreous reactions can be subdivided into degenerative and reactive changes. The reactive changes are composed of direct reactions occurring at the site of an irritation, trauma, or surgical insult and indirect reactions developing either all through the vitreous body or in an area distant to the irritating insult. Every clinician knows that the vitreous may react even to simple cataract surgery [7]. Somehow and sometimes, the occurrence of cystoid macular edema is linked to this reaction [6]. Most clinicians suspect that there also is a vitreous reaction to intraocular lens implantation. Three cases of eyes containing lens implants are used for a first attempt at the histological study and demonstration of direct vitreous reaction next to the implant surface in the present paper.

\section{Histopathological description}

First case. A Binkhorst four-loop lens implant was removed by Dr. Alan Sugar of this Department of Ophthalmology from the eye of a 78 year old female about one and a half years after its implantation. There was a history of repeated dislocations of the implant and chronic iritis as well as so-called vitritis. After its removal, the implant was fixed in $10 \%$ buffered Formalin. Study with the Implant Cytology Technique [8] revealed on the posterior surface of the optical portion of the implant a thin eosinophilic membrane containing relatively few inactive fibroblast-like cells. The front aspect of the optical portion exhibited remnants of a more developed cellular membrane, most of which was lost during the surgical removal of the implant.

The posterior aspect of this implant had been in direct contact with the anterior vitreous. Study of the implant revealed extensive and very irregular structures composed 


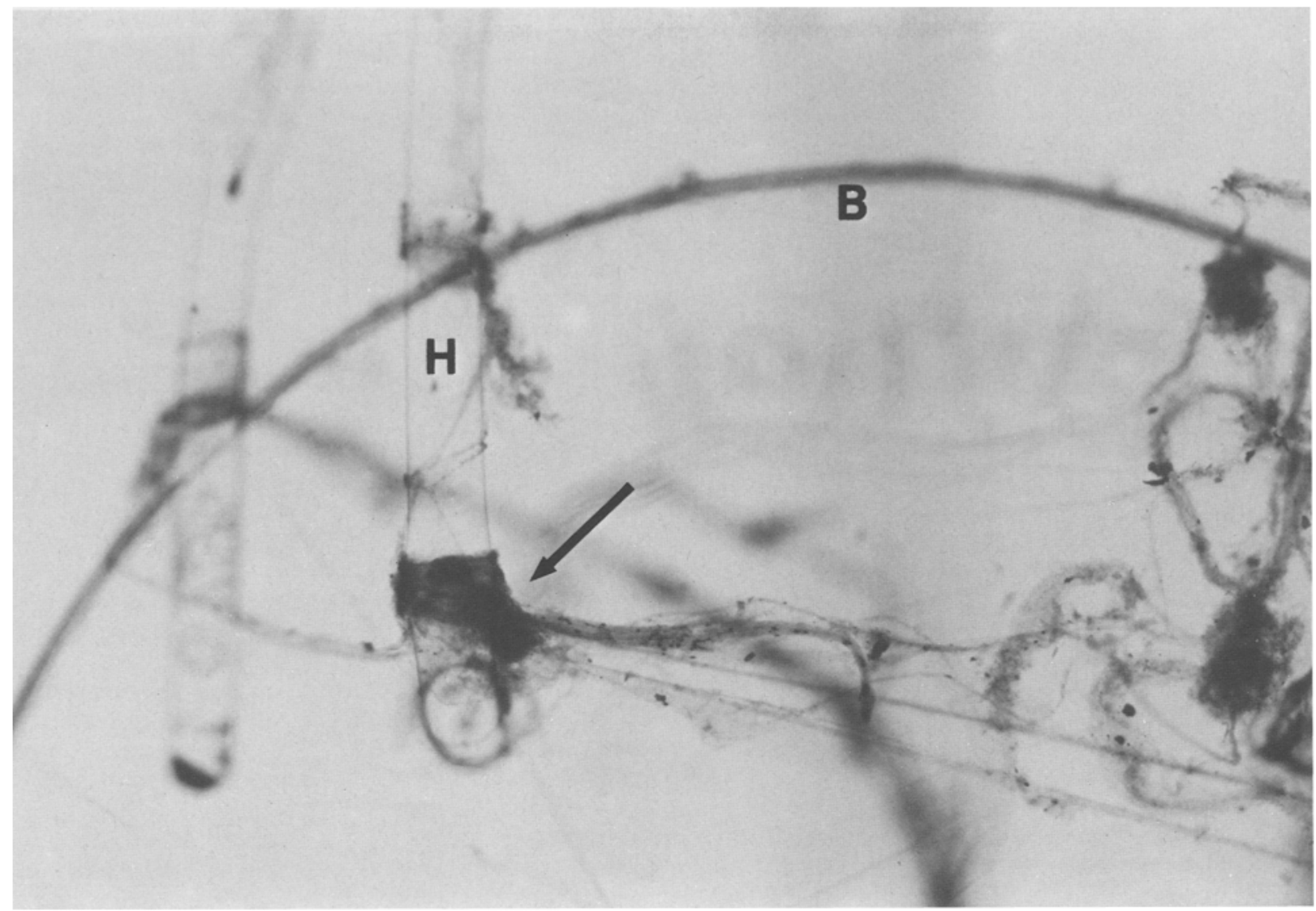

Fig. 1. First case, Spiraling vitreous strands wound around haptics $(H)$ of the lens implant for firm anchoring (arrow). The lens with its border $(B)$ and the second haptic loop are out of focus. - Lens Implant Cytology, H and E stain, microphotograph $\times 50$

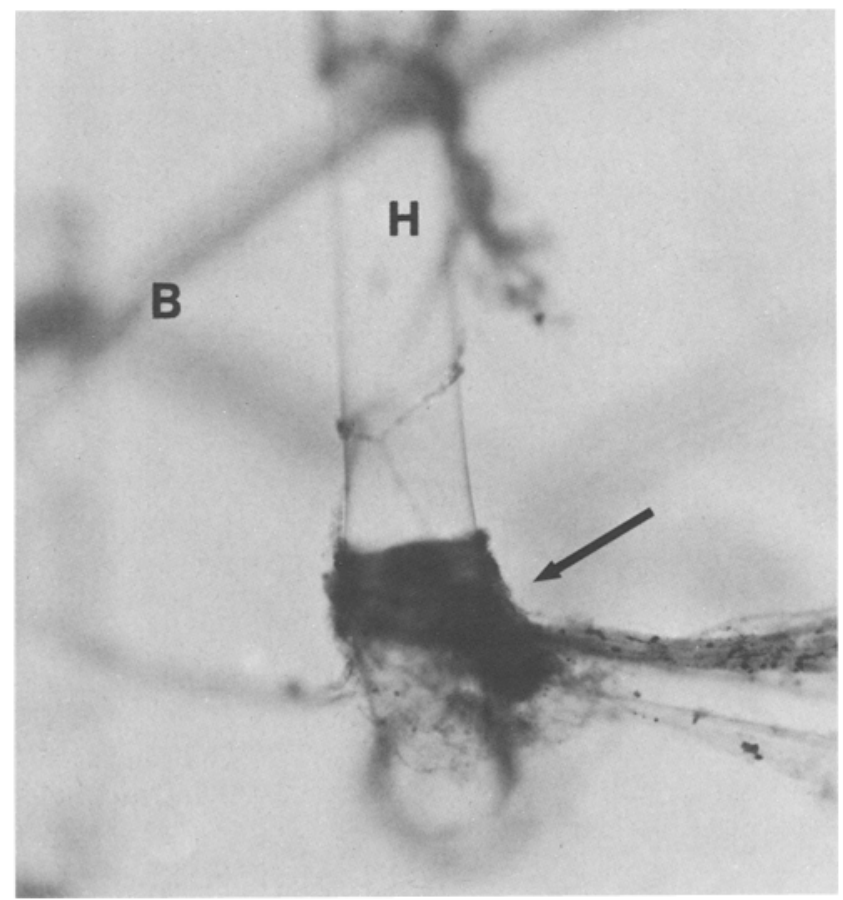

Fig. 2. First case, Higher power of the insertion of the vitreous strand (arrow) containing small pigment-filled cells and free pigment on one of the haptics of the implant. The border of the implant $(B)$ and other spiraling vitreous bands are out of focus. - Lens Implant Cytology, $\mathrm{H}$ and $\mathrm{E}$ stain, microphotograph $\times 80$ of spiraling vitreous bands mainly attached to the posterior haptics (Figs. 1 and 2). These structures had taken an eosinophilic stain and they contained small elongated mononuclear cells, pigment granules of very irregular sizes, and whole erythrocytes. The strand-like formations appeared to be wound around posterior haptics several times. They were composed of smaller strands and in some areas they were seen to split up and the smaller strands formed delicate string-like formations on and around the haptics by themselves (Fig. 2). These irregular strands and bands were connected to and associated with more membranous formations of similar structure (Figs. 3 and 4). These membranous formations were in the first case not firmly attached to any part of the posterior surface of the implant, but they were continuous with the strands and these, in turn, were firmly anchored to the haptics. The membranes also exhibited small cells with round or oval nuclei, cells completely filled with pigment, free pigment granules of many sizes, and occasional normal-looking as well as degenerating erythrocytes.

Second case. Similar strand-like formations and membranes were seen on the posterior surface of a Federow implant of the "Sputnik type". This Sputnik lens was removed by Dr. Roger Meyer of this Ophthalmology Department during penetrating keratoplasty almost exactly five years after its implantation. The eye with the Sputnik lens had developed severe corneal edema. Again, the implant was fixed immediately after its removal in $10 \%$ buffered Formalin. 


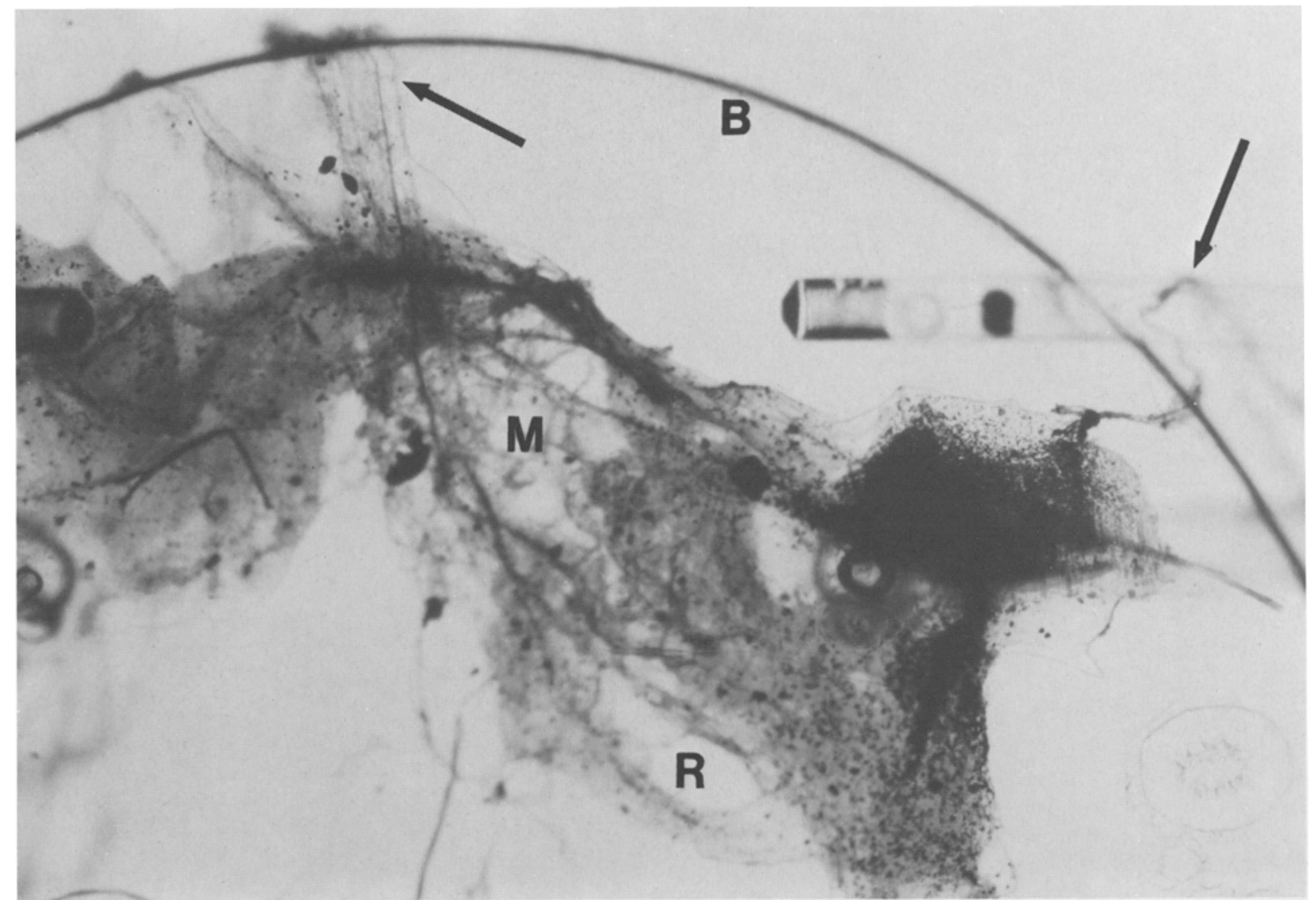

Fig. 3. First case, Fibrous vitreous membrane $(M)$ containing pigment, small cells, and erythrocytes attached to different parts of the posterior aspect of the implant by strands (arrows). The region indicated by $\mathrm{R}$ is seen at higher power in Fig. 4. - Lens Implant Cytology, $\mathrm{H}$ and $\mathrm{E}$ stain, microphotograph $\times 50$

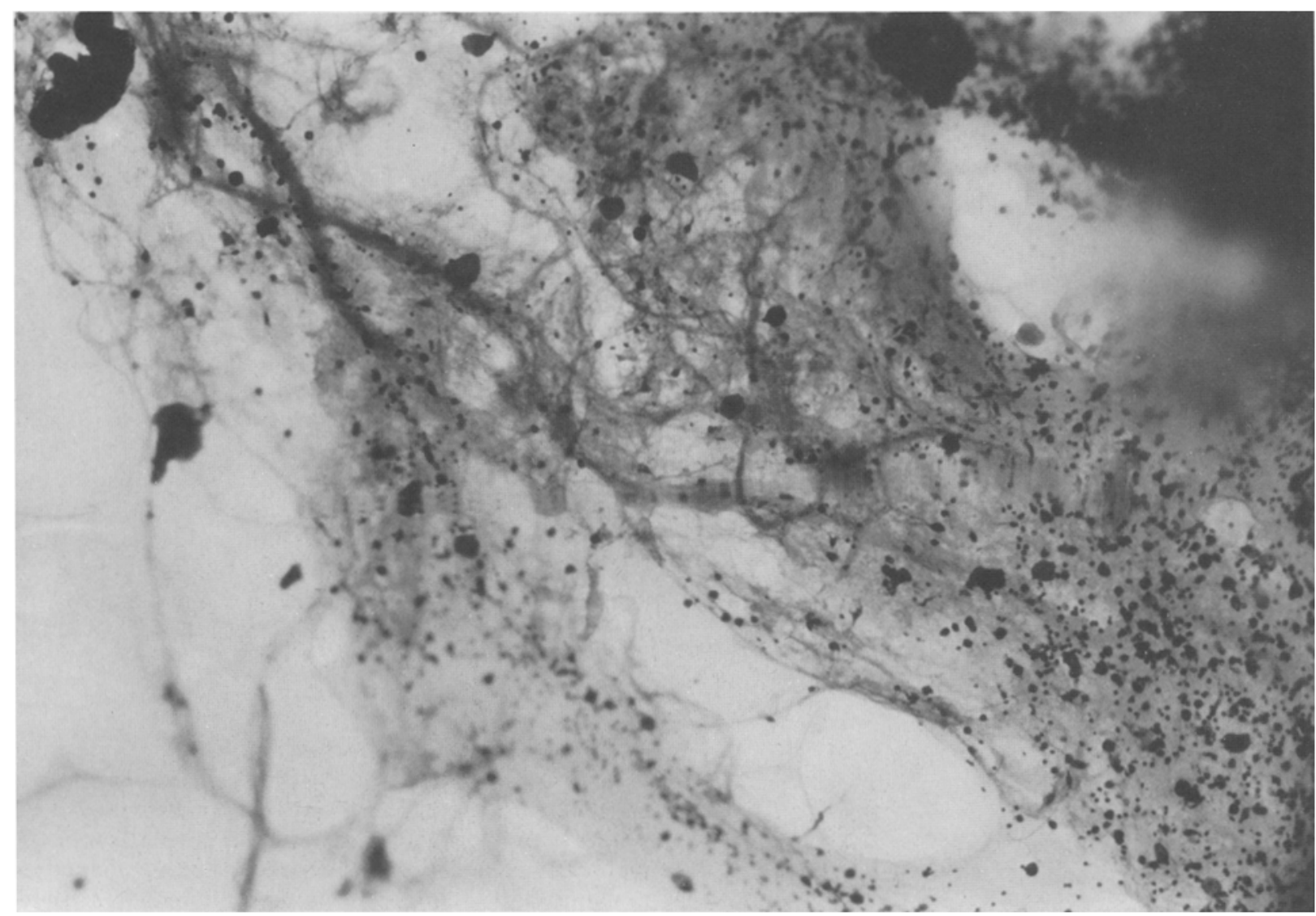

Fig. 4. First case, Higher power of part of the fibrous membrane on the lens implant seen in Fig. 3. This membrane is composed of densely arranged fibers, pigment, blood remnants, and small fibroblast-like cells. - Lens Implant Cytology, H and E stain, microphotograph $\times 100$ 


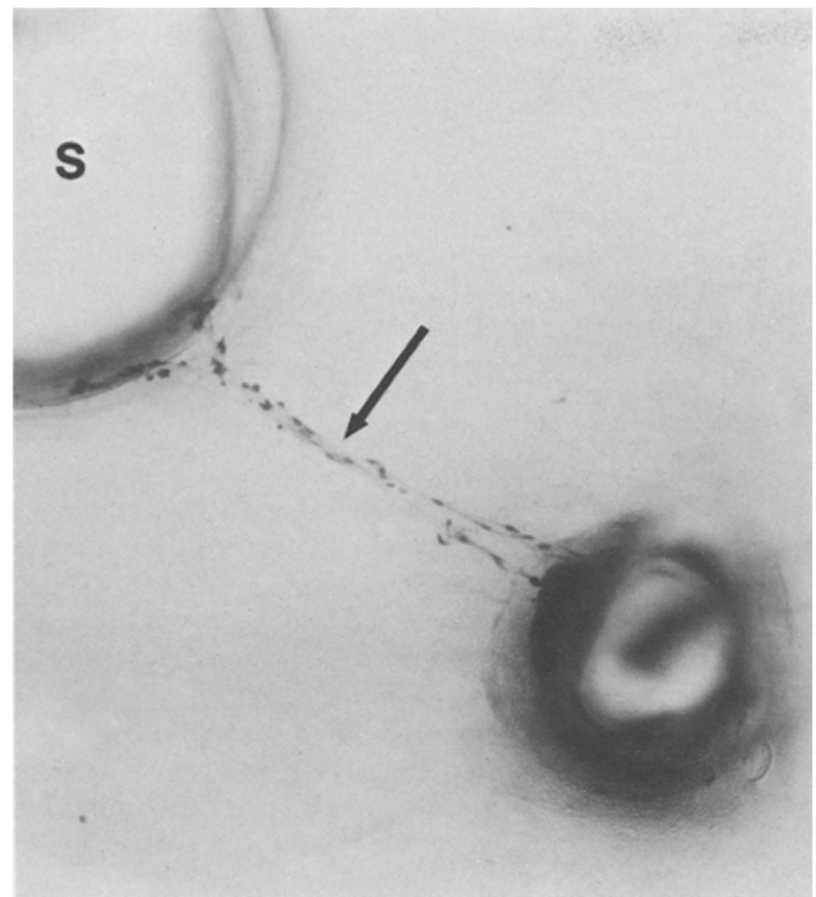

Fig. 5. Second case, A thin vitreous strand (arrow) stretched between a suture hole $(S)$ and the insertion of a haptic rod on the posterior aspect of the implant. The small elongated cells in the strand are clearly visible. - Lens Implant Cytology, H and E stain, microphotograph $\times 200$
Study with the Implant Cytology Technique again revealed portions of a cellular membrane containing fibroblast-like cells as well as foreign body giant cells covering the surface of the implant. Strands, bands, and membranes of eosinophilic material firmly attached to the haptics on the posterior surface of this lens are of interest for the present study (Figs. 5-7). The delicate strands again contained small cells (Fig. 5) as well as much intracellular and extracellular pigment. The larger strands were of similar composition. Parts of a dense membrane were attached to the posterior aspect of the haptics (Figs. 6 and 7). These membranes were rather dense and eosinophilic. They contained pigment granules as well as occasional small cells. Due to their arrangement and rather regular structure they were suspected to be parts of the original anterior hyaloid face. However, these dense membranes had delicate connecting strands extending to the haptics and winding around these (Fig. 6). Even the thickest portions of the membranes stretched between the large posterior loops of this implant were not truly cellular and did not have the appearance of scar tissue with blood vessels (Fig. 6). Grossly and histologically all strands and membranes on the posterior aspect of this implant resembled condensed vitreous structures.

Third case. This 90 year-old female had extracapsular cataract surgery with placement of a posterior chamber lens implant in her left eye in January 1981. A membrane of remaining lens substance formed and was removed surgically a few months later. Soon after this was done, the

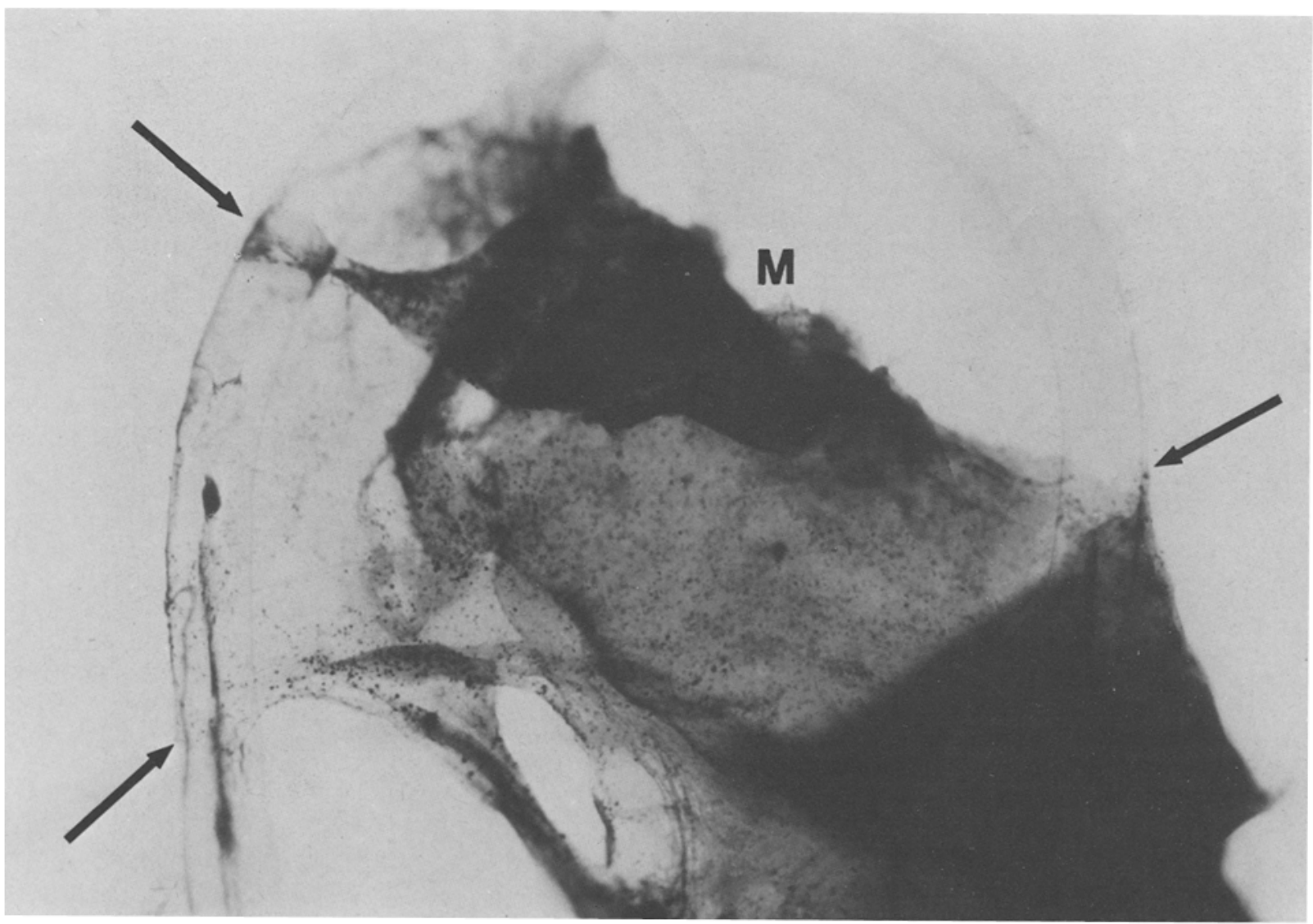

Fig. 6. Second case, Low power view of part of a thick vitreous membrane $(M)$ stretched on the posterior aspect of one of the haptic loops. There are firm membranous and strand-like connections to the haptics (arrows). - Lens Implant Cytology, H and E stain, microphotograph $\times 30$ 


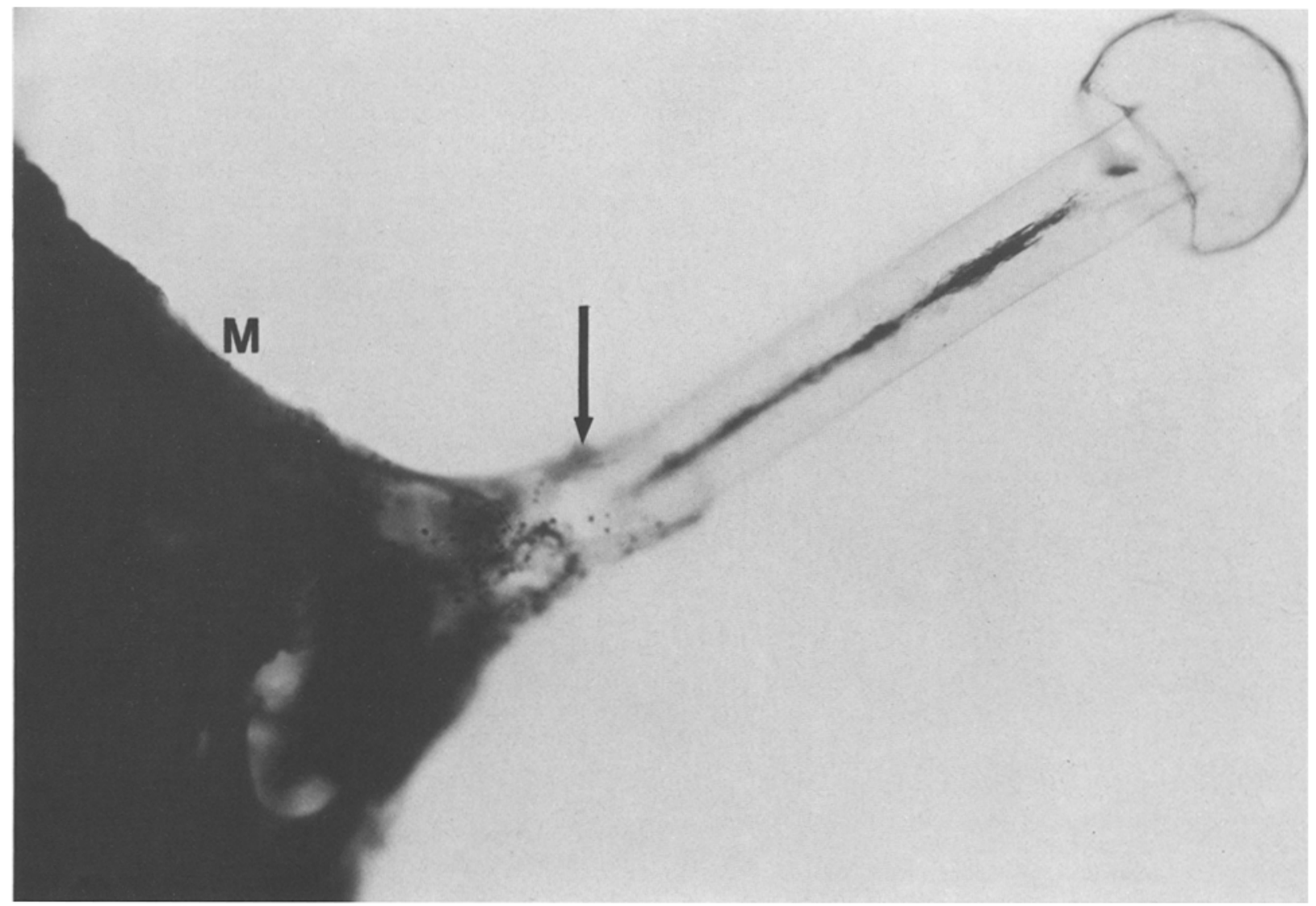

Fig. 7. Second case, One of the mushroom-like supports of the implant sticking out of the firm attachment (arrow) of a densely fibrous vitreous membrane $(M)$. - Lens Implant Cytology, H and E stain, photomicrograph $\times 50$

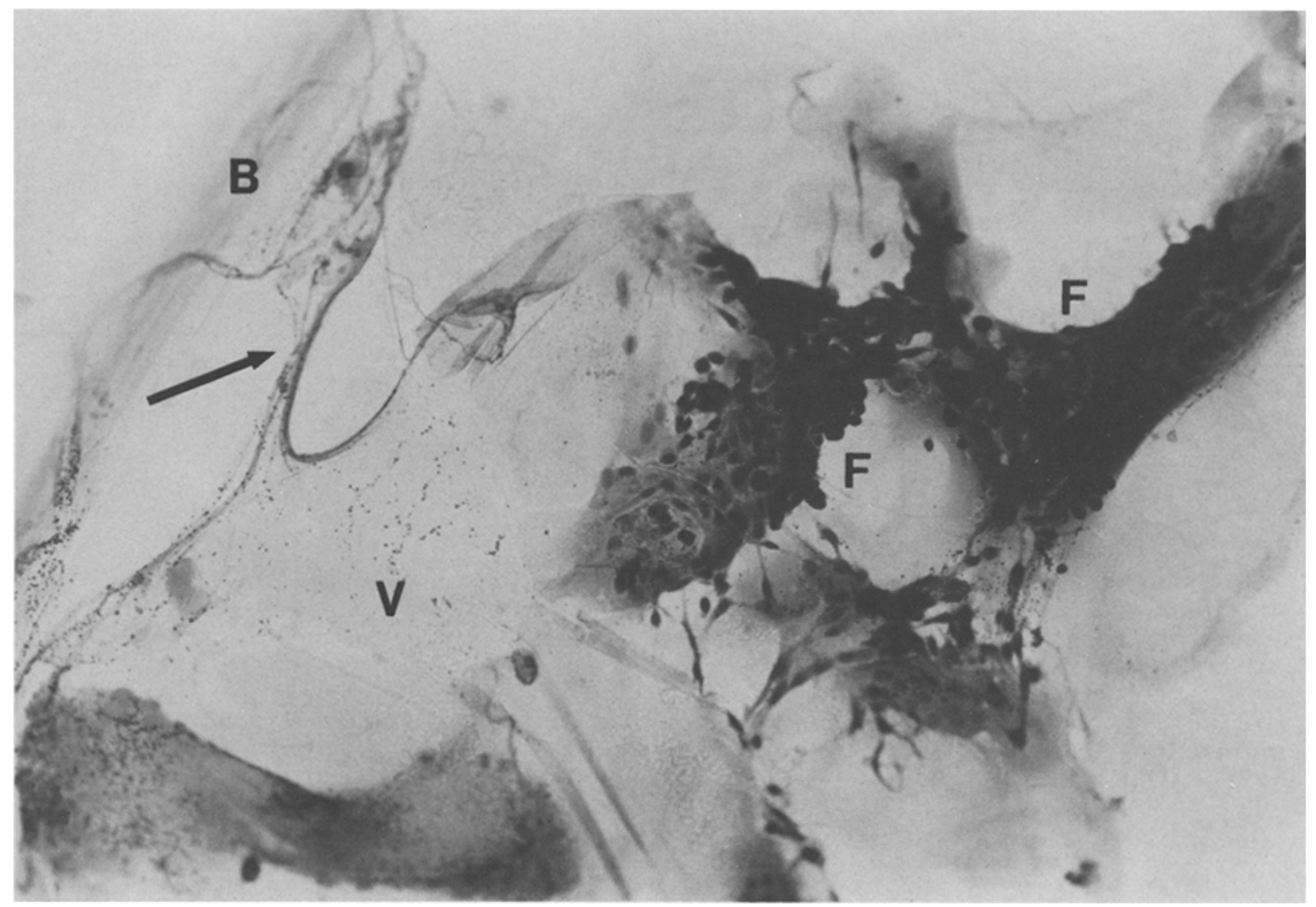

Fig. 8. Third case, Posterior aspect of the border $(B)$ of the implant exhibiting large foreign body giant cells and some fibroblast-like cells $(F)$. There are no cells in the region of the attachment of formed vitreous $(V)$ with some pigment and strand-like condensations. - Lens implant Cytology, $\mathrm{H}$ and $\mathrm{E}$ stain, photomicrograph $\times 100$ 


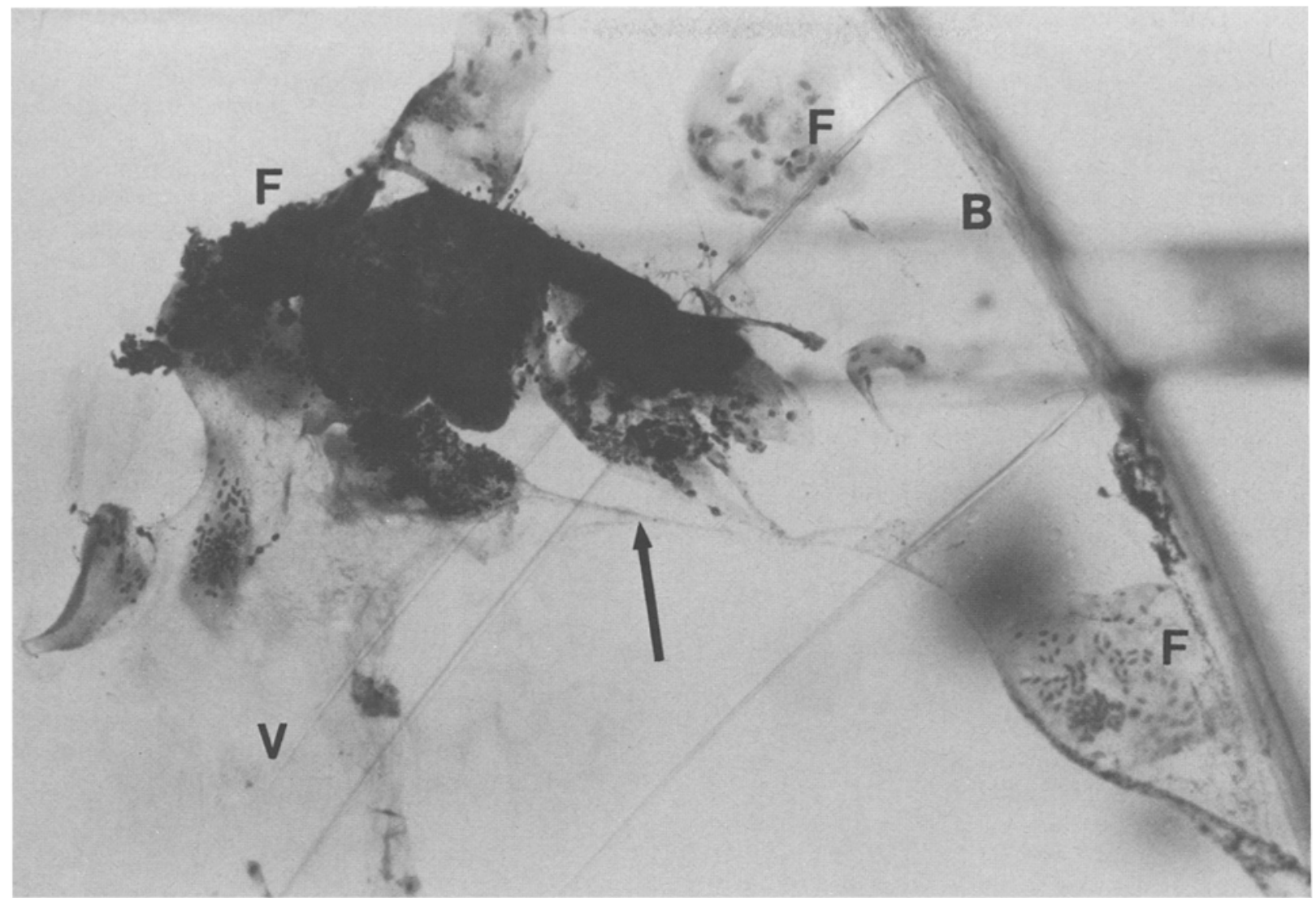

Fig. 9. Third case, An island of irregular foreign body giant cells $(F)$ near the border of the implant $(B)$ surrounded by clear vitreous attached directly to the posterior implant surface with few strands (arrow). - Lens Implant Cytology, $\mathrm{H}$ and $\mathrm{E}$ stain, microphotograph $\times 100$

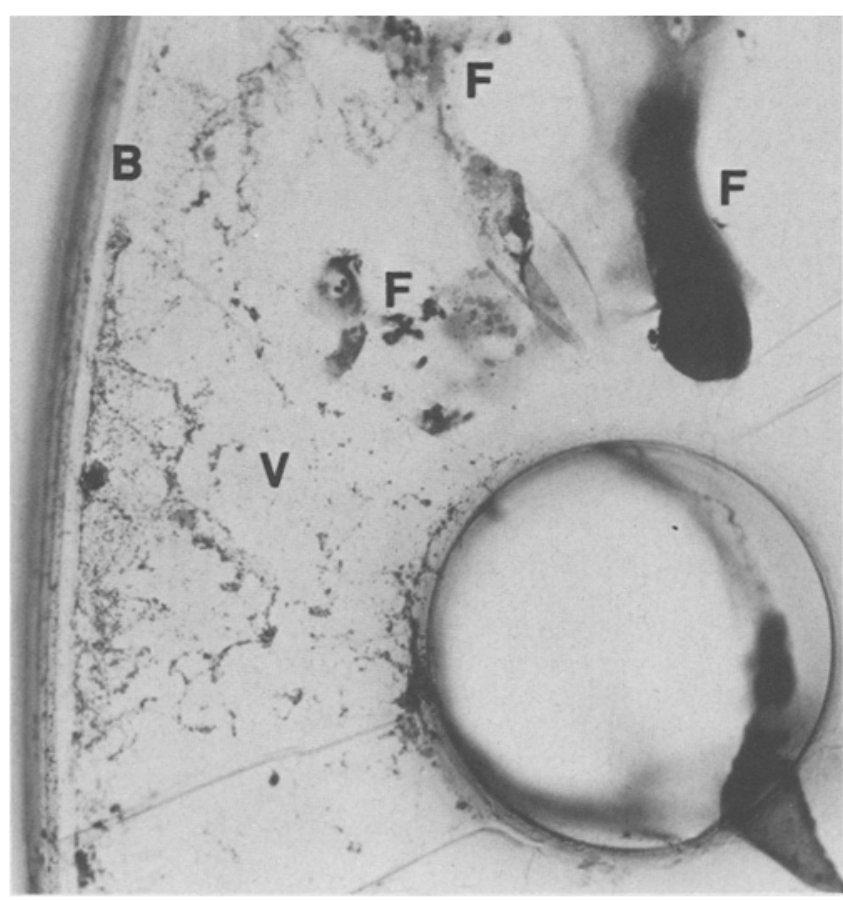

Fig. 10. Third case, An area of attachment of formed vitreous containing pigment $(V)$ to the naked posterior border region $(B)$ of the implant near a hole. Foreign body giant cells $(F)$ are seen above the zone of vitreous attachment. The limits between vitreous and giant cell protoplasm are not clear. - Lens Implant Cytology, $\mathrm{H}$ and $\mathrm{E}$ stain, photomicrograph $\times 40$ eye started to develop bullous keratopathy. Conservative treatment failed and a corneal graft was done by Dr. Roger Meyer of this Eye Department on 9-3-82. The lens implant was removed by Dr. Meyer along with parts of the cataract membrane during the keratoplasty and all tissues were immediately fixed in 10\% Formalin.

Study of the corneal button revealed endothelial atrophy and secondary subacute keratitis with early superficial neovascularization. The cataract membrane was composed of lens capsule and partly calcified lens substance. Vitreous was seen intermixed with the lens remnants and numerous macrophages were present. These macrophages were in the process of phagocytizing degenerating lens substance. There also was diffuse hemorrhage present.

The lens implant had an irregular membrane mainly composed of foreign body giant cells and fibroblast-like cells on its anterior surface. The giant cells were the largest near the border of the optical portion of the implant. The posterior surface of the implant had been exposed to vitreous. There were large giant cells on the posterior surface near the border in some places (Figs. 8-10). However, the cellular membrane had not developed in the region of the vitreous attachment to the implant. The vitreous contained strands and veil-like membranes with marginal condensations (Figs. 8 and 9). The vitreous contained pigment granules (Figs. 9 and 10). In other places the vitreous was firmly and directly attached to the implant and did not exhibit strands or condensations (Fig. 10). After $\mathrm{H}$ and E staining the limit between vitreous and the protoplasm of the large giant cells was not clearly visible (Figs. 8 and 9). The haptics 
of the posterior chamber lens were involved with pigment containing vitreous strands in a similar way to that seen in the first case.

\section{Discussion}

Intraocular lens implants are commonly seen in direct interaction with vitreous of different parts and different conditions: intact vitreous face, portions of interrupted vitreous face, formed anterior vitreous body, fluid vitreous, and combinations of these. The vitreous face is seen to react to adjacent implants with fibrotic thickening, strand formation, pigment deposition, and abnormal cellularity. Furthermore, vitreous face can make firm attachments to the surface of the implants - most commonly its haptics or the posterior surface of its optics. Ruptured anterior vitreous face typically wraps around haptic portions of iris-supported or posterior chamber lenses.

Formed anterior vitreous makes rather firm connections to all parts of the posterior aspect of lens implants with fibrous-appearing strands. Surprisingly, these strands are commonly wound around the haptics several times and, thus, they are firmly anchored to the implants. The surgical history does not usually explain the development of the winding attachments and the impression is that these have actively grown - somewhat like roots of a tree around a gas pipe in the ground.

The observation of numerous small bipolar cells within the thickened vitreous membranes and the vitreous strands attached to the implants in the present cases is helpful for the explanation of these rather bizarre strands and bands. These cells often contain pigment in their protoplasm, they are quite similar to the so-called fibroblast-like cells commonly found on the surface of lens implants [9-14], they are part of the fiber bundles in the vitreous, and they are arranged in the direction of these fibers. They do not resemble active macrophages. It is suspected that these cells take an active part in the formation of the fibrous strands wound around the haptics and the reinforcements of the vitreous membranes next to the implants.

The firm attachment of the anterior vitreous face as well as the reactive strands and veils of fibrous- or homogenous-appearing formed vitreous clearly interferes with the formation of the usual cellular membranes on the plastic surface of lens implants [8-14]. This may well be a problem, since the formation of these separating cell membranes is believed to be a beneficial process in the long run. Fluid vitreous, in contrast, does not visibly react with the implants and it also does not interfere with the formation of the cellular membranes. With other words, there appears to be no real difference between cellular membranes formed on intraocular lenses surrounded by aqueous humor or by fluid vitreous.

Evidence of bleeding in the form of well-preserved erythrocytes, degenerating blood cells, and blood pigment remnants is a practically constant component of reactive vitreous membranes and strands next to intraocular lens implants. The few special stains that have been done seem to indicate that the pigment seen in these strands and mem- branes is partly melanin and partly hemosiderin. Irregularities on lens implants like the insertion of haptics or suture holes, for example, are clearly the most common sites for the attachment of vitreous strands and membranes. Anterior chamber lenses, in principle, show much less evidence for vitreous involvement and vitreous attachment in comparison to iris supported and posterior chamber lenses.

The observations of this study clearly indicate that vitreous face and exposed formed vitreous touching the plastic surface of intraocular lens implants may change back into living structure populated by fibroblast-like cells. This structure has the ability to form strands and fibers which anchor the vitreous to the haptics and to the surface of the plastic implants. The questions about the origin of the cells, the role of the frequently associated presence of blood and blood remnants, and the extent of the vitreous involvement as well as the relation to vitreous shrinkage cannot as yet be answered. Practical importance of these questions demands that we should make a great effort to find the answers soon.

\section{References}

1. Reese AB, Jones IS, Cooper WC (1967) Macular changes secondary to vitreous traction. Amer J Ophth 64:544-549

2. Heller MD, Irvine SR, Straatsma BR, Foos RY (1971) Wound healing after cataract extraction and position of the vitreous in aphakic eyes as studied postmortem, Trans. Amer Ophth Soc 69:245-262

3. Heller MD, Straatsma BR, Foos RY (1972) Detachment of the posterior vitreous in phakic and aphakic eyes. Mod Probl Ophth 10:23-36

4. Foos RY (1972) Posterior vitreous detachment. Trans Amer Acad Ophth Otolaryngol 76:480-497

5. Tolentino FI, Schepens CL, Freeman HM (1976) Vitreoretinal Disorders: Diagnosis and Management, W.B. Saunders, Philadelphia

6. Ho PC, Tolentino FI (1982) The role of vitreous in aphakic cystoid macular edema: A review, Amer. Intra-Ocular Implant Soc J, 8:258-264

7. Irvine SR (1953) A newly defined vitreous syndrome following cataract surgery, Amer J Ophth 36:599-619

8. Wolter JR (1982) Lens implant cytology, Ophth Surg 13:939-942

9. Wolter JR (1982) Cell life on the surface of lens implants, von. Graefe's Arch Ophth 218:244-249

10. Wolter JR (1982) Foreign body giant cells on intraocular lens implants, von Graefe's Arch Ophth 219:103-111

11. Wolter JR, Felt DP (1983) Fibroblastic activity on failing intraocular lenses, Ophth Surg 14:57-64

12. Wolter JR (1982) Pigment in cellular membranes on intraocular lens implants, Ophth Surg 13:726-732

13. Wolter JR (1983) Foreign body reaction to firm nuclear lens substance, Ophth Surg, in print

14. Wolter JR (1983) Reactive membrane on a lens implant: three months after implantation, von Graefe's Arch Ophth, in print

15. Wolter JR, Croasdale RE, Bahn CF (1980) Reactions to an anterior chamber lens: two years after implantation, Ophth Surg $11: 794-800$

16. Wolter JR (1981) The histopathology of cystoid macular edema, von Graefe's Arch Ophth 216:85-101

Received December 22, 1982 